\title{
HPV16 antibodies as risk factors for oropharyngeal cancer and their association with tumor HPV and smoking status
}

\author{
Karen S. Anderson ${ }^{a}, *$, Kristina R. Dahlstrom ${ }^{b}$, Julia N. Cheng ${ }^{a}$, Rizwan Alam ${ }^{a}$, Guojun Li ${ }^{b}$, Qingyi Wei ${ }^{c}$, \\ Neil D. Gross ${ }^{\mathrm{b}}$, Diego Chowell ${ }^{\mathrm{a}, \mathrm{d}}$, Marshall Posner ${ }^{\mathrm{e}}$, Erich M. Sturgis ${ }^{\mathrm{b}}$ \\ ${ }^{a}$ Center for Personalized Diagnostics, The Biodesign Institute, Arizona State University, Tempe, AZ, United States \\ ${ }^{\mathrm{b}}$ Department of Head and Neck Surgery, Division of Surgery, The University of Texas MD Anderson Cancer Center, Houston, TX, United States \\ ${ }^{\mathrm{c}}$ Duke Cancer Institute, Duke University Medical Center, Durham, NC 27710, United States \\ ${ }^{\mathrm{d}}$ Simon A. Levin Mathematical, Computational, and Modeling Sciences Center, Arizona State University, Tempe, AZ, United States \\ e Tisch Cancer Institute, Icahn School of Medicine at Mount Sinai, New York City, NY, United States
}

\section{A R T I C L E I N F O}

\section{Article history:}

Received 4 January 2015

Received in revised form 16 March 2015

Accepted 15 April 2015

Available online 6 May 2015

\section{Keywords:}

Serology

Antibodies

Biomarker

HPV

Oropharyngeal cancer

Head and neck cancer

\begin{abstract}
S U M M A R Y
Background: Antibodies (Abs) to the HPV16 proteome increase risk for HPV-associated OPC (HPVOPC). The goal of this study was to investigate the association of a panel of HPV16 Abs with risk for OPC as well as the association of these Abs with tumor HPV and smoking status among patients with OPC. Methods: IgG Abs to the HPV16 antigens E1, E2, E4, E5, E6, E7, L1, L2 were quantified using a programmable ELISA assay. Sera were obtained from 258 OPC patients at diagnosis and 250 healthy controls. HPV16 tumor status was measured by PCR for 137 cases. Multivariable logistic regression was used to calculate odds ratios for the association of HPV16 Abs with risk for OPC.

Results: HPV16 E1, E2, E4, E5, E6, E7 and L1-specific IgG levels were elevated in OPC patients compared to healthy controls $(p<0.05)$. After multivariable adjustment, Ab positivity for NE2, CE2, E6, and/or E7 was associated with OPC risk (OR [95\% CI], 249.1 [99.3-624.9]). Among patients with OPC, Ab positivity for these antigens was associated with tumor HPV status, especially among never or light smokers (OR [95\% CI], 6.5 [2.1-20.1] and OR [95\% CI], 17.5 [4.0-77.2], respectively).

Conclusions: Antibodies to HPV16 proteins are associated with increased risk for HPVOPC. Among patients with OPC, HPV16 Abs are associated with tumor HPV status, in particular among HPV positive patients with no or little smoking history.
\end{abstract}

(c) 2015 Elsevier Ltd. All rights reserved.

\section{Introduction}

Oropharyngeal cancer (OPC) is a subset of head and neck cancer, which is ranked as the sixth most common cancer worldwide with 405,000 new cases and 200,000 deaths annually [1]. Tobaccoassociated OPC, which is associated with somatic mutations in $\mathrm{p} 53$, is decreasing in incidence, but human papillomavirusassociated OPC (HPVOPC) has increased in the U.S. by $225 \%$ between 1984 and 2004 [2]. HPV type 16 accounts for $85-90 \%$ of HPV-associated cases of OPC [3,4]. Epidemiological evidence

Abbreviations: Abs, antibodies; CV, coefficient of variation; HR HPV, High Risk Human Papilloma Virus; ISH, in situ hybridization; IVTT, in vitro transcription/translation; OPC, oropharyngeal cancer; OR, odds ratio; SD, standard deviation. * Corresponding author at: Biodesign Institute, Arizona State University, PO Box 876401, Tempe, AZ 85287, United States. Tel.: +1 480965 6982; fax: +1 480965 3051 .

E-mail address: Karen.Anderson.1@asu.edu (K.S. Anderson). supports a causal role for HPV in OPC, including the association with lifetime numbers of vaginal and oral sex partners [3,5] and presence of HPV DNA in oral exfoliated cells [3,6-10]. HPV is detectable and persistent in tumors [11-14], contains viral oncogenes [15-17], can transform target cells $[18,19]$, and induce tumors in transgenic mice $[20,21]$.

Unlike cervical cancer, there exists no sensitive and selective screening method for the early detection of HPVOPC. The HPV16 genome consists of six early genes (E1, E2, E4, E5, E6, and E7) and two late genes (L1 and L2) that constitute the viral capsid. Serum antibodies (Abs) to HPV16 E6 and E7 have been detected in a subset of patients with OPC [22,23], with Abs to E6 and/or E7 present in $67 \%$ of HPV-positive OPC cases [24]. Seropositivity for HPV16 E6 and E7 are strongly associated with increasing odds of HPV-positive OPC (OR 58-67) [25,26] and with improved prognosis $[27,24,28]$. HPV16 Abs to E6 have been detected in $34.8 \%$ of OPC patients up to 10 years prior to clinical diagnosis [11], 
suggesting that HPV serology may yield biomarkers for early detection of OPC. In a pilot study, we detected Abs to both E6 and E7 proteins in OPC patient sera, but also detected Abs to the HPV16 E1 and E2 proteins [22]. This suggests that serology of additional HPV antigens may improve detection of HPVOPC.

In this study, we investigated the association of a panel of HPV16 Abs with risk of OPC. We used an extensive collection of sera from newly-diagnosed OPC patients and cancer-free controls to evaluate the association between HPV16 proteome-wide serology and disease status as well as tumor HPV and smoking status among cases.

\section{Material and methods}

\section{Patient sera}

Patients with newly diagnosed, histopathologically confirmed, and previously untreated OPC who were participating in a large ongoing molecular epidemiology study of head and neck cancer at the University of Texas MD Anderson Cancer Center in Houston, TX were eligible for the study. All participants were recruited between January 2006 and September 2008. Participants provided demographic and exposure history, including smoking and alcohol use, using a standardized questionnaire and provided a blood sample for biological testing. Sera used in this analysis were collected from OPC patients prior to initiation of treatment $(n=258)$. Healthy control sera were collected from genetically unrelated visitors or companions of patients to the head and neck clinic during the same time period. Controls were frequency matched to cases on age ( \pm 5 years), gender, and race $(n=250)$. Approximately $93 \%$ of cases and $85 \%$ of controls who were eligible agreed to participate in the study. All samples were collected using a standardized sample collection protocol and stored at $-80^{\circ} \mathrm{C}$ until use. Written informed consent was obtained from all subjects under institutional review board approval.

\section{HPV DNA cloning and expression}

Plasmids containing HPV16 genes [29] were expressed as a C-terminal GST-fusion protein using human HeLa cell lysate [30] (Thermo Scientific, Waltham, MA) per manufacturer's instructions. The HPV16 E2 gene was expressed as N- and C-terminal fragments for optimal protein expression [22]. GST was expressed as a negative control protein. All recombinant DNA research was performed in accord with NIH guidelines under institutional biologic safety review and approval.

\section{Programmable protein (RAPID) ELISA}

ELISAs were performed essentially as described [31], with modifications [32]. Protein was expressed from template cDNA and captured onto 96-well plates coated with anti-GST Ab (GE Healthcare, Piscataway, NJ). Sera were diluted 1:100 and blocked with $E$. coli lysate. Cases and controls were analyzed simultaneously in duplicate. Horseradish peroxidase (HRP) anti-human IgG Abs (Jackson ImmunoResearch Laboratories, West Grove, PA) were added at 1:10,000, and detected using Supersignal ELISA Femto Chemiluminescent substrate (Thermo Scientific). Luminescence was detected as relative light units (RLU) on a Glomax 96 Microplate Luminometer (Promega, Madison, WI) at $425 \mathrm{~nm}$. To control for non-specific and GST-specific antibodies, the ratio of RLU for individual HPV-specific Abs to the RLU for the control GST-antigen was measured. To establish cut-off values, an RLU ratio $>$ (the mean +3 standard deviations) of 125 randomly chosen control samples was designated positive. These levels were E1: 2.66; NE2: 2.29; CE2: 4.35; E4: 2.58; E5: 1.69; E6: 2.01; E7: 1.99;
L1: 1.83; L2: 3.57. The controls chosen to establish cut-off values were not statistically significantly different with respect to age, sex, race, smoking, or alcohol use from the controls not used.

\section{Reproducibility of RAPID ELISA}

To determine the reproducibility of the RAPID ELISA assay, replicates for E6 serology were performed with 8 replicates on 4 consecutive days. RLU ratios (E6-GST: GST control) among RAPID ELISAs processed on the same day showed intra-assay CVs of $0.2-7 \%$, and RLU ratios between plate-based arrays processed on 4 consecutive days demonstrated inter-assay CVs of $12-17 \%$.

\section{Tumor HPV DNA detection by PCR}

Diagnostic in-house paraffin-embedded tissue was obtained following histopathologic confirmation of the diagnosis for determination of tumor HPV status [33]. DNA was extracted using a tissue DNA extraction kit (Qiagen Inc., Valencia, CA). Tumor tissue from the study subjects was tested for the presence of HPV16 E6 or E7 regions using PCR-based type-specific assays and each subject was classified as HPV-positive or HPV-negative based on these results. Samples were run in triplicate with positive (Siha cell line) and negative (TPC- 1 cell line) controls and $\beta$-actin as DNA quality control.

\section{Statistical analysis}

Categorical variables were created to describe study subjects' demographic, clinical, and exposure (smoking and alcohol) history. A subject was considered an ever-smoker if they had smoked at least 100 cigarettes during their lifetime and an ever-drinker if they had drunk alcoholic beverages at least once a week for a year or more during their lifetime. Subjects who previously smoked or drank alcohol but had not done so in the year prior to their diagnosis were considered former-smokers and former-drinkers, respectively.

Demographic and clinical variables of interest were analyzed using standard descriptive statistical methods. Differences between groups were compared using chi-square or Fisher's exact (when cell frequencies <5) tests for categorical variables and Student's t-test, with adjustment for unequal variances where appropriate, for continuous variables. Mean Ab values were plotted for cases and controls and compared using Mann-Whitney nonparametric analysis (GraphPad Prism version 5.0c, San Diego, CA). Odds ratios (OR) with 95\% confidence intervals (CI) were calculated using logistic regression models with adjustment for possible confounding factors to determine the association between pre-treatment $\mathrm{Ab}$ status and OPC. The association between pretreatment Ab status and tumor HPV16 and smoking status among cases was also evaluated (Stata 12.0, StataCorp, College Station, $\mathrm{TX}$ ). A $p$-value of $<.05$ was considered significant and all tests were 2-sided.

\section{Results}

\section{Subject characteristics}

Ab levels specific for HPV16 proteins and GST control protein were compared in sera from 258 cases of OPC and 250 age-, gender- and race-matched controls. Two cases were omitted from further study because they presented with distant metastases at diagnosis, leaving a sample size of 256 cases. The demographics of cases and controls are presented in Table 1 . There were no significant differences between cases and controls with respect to age, gender, and race (Table 1 ). However, cases were more likely 
to be current smokers while controls were less likely to be current alcohol drinkers ( $p=0.007$ and $p<0.001$, respectively; Table 1$)$. The majority of cases was derived from the tonsils or base of tongue (95\%) and was stage III/IV (92.6\%) at presentation. Among the 256 cases, HPV16 status (as determined by tumor HPV16 PCR for E6 and E7) were available for 137 cases, with 111 cases positive for HPV16 (81\%).

\section{Detection of HPV16 Abs by programmable ELISA}

Results of the RAPID ELISA for serum IgG Abs to HPV16 antigens for OPC cases and healthy controls are shown in Fig. 1. The medians and ranges of these values for each individual antigen are presented in Supplementary Table 1. In the total OPC samples (unselected by HPV status), all HPV16 Abs except L2 were significantly higher among patients with OPC than healthy controls $(p<0.05$, Supplementary Table 1 and Fig. 1). A higher proportion of patients with OPC than healthy controls were seropositive for each of these Abs (Table 2). Using cut-off values derived from the healthy controls ( $n=125,>3$ SDs over the mean), at least one HPV16 early gene Ab was detected in the sera of $210 / 256(82.0 \%)$ of OPC cases, compared with $10 / 250$ (4.0\%) of healthy controls (Table 2 ). A high proportion of patients were positive for IgG Abs specific for HPV16 E1 (144/256, 56.3\%), NE2 (104/256, 40.6\%), CE2 (137/256, 53.5\%), E4 (61/256, 23.8\%), E6 (148/256, 57.8\%), and/or E7 (148/256, 57.8\%). In comparison, only 9 cases (3.5\%) were positive for E5 Abs, 15 cases (5.9\%) were positive for L1 Abs, and none were positive for L2 Abs.

Risk for OPC was estimated by calculating OR (95\% CI), adjusted for age, smoking, and alcohol drinking status (Table 2). The OR for E1, E2, E6, and E7 Abs ranged from 86 to 171 . While the $95 \% \mathrm{CI}$ are wide, an extremely high risk of OPC was associated with seropositivity for the E1 protein ( $\mathrm{OR}=171)$, the C-terminal portion of E2 $(\mathrm{OR}=158)$, the $\mathrm{E} 6$ protein $(\mathrm{OR}=131)$, and for the $\mathrm{E} 7$ protein $(\mathrm{OR}=147)$. Being seropositive to any antigen was associated with a 194-fold increased risk of OPC, while being seropositive to an early protein was associated with a 244-fold increased risk of OPC, and being seropositive to a late protein was associated with a 3-fold increased risk of OPC.

\section{Association of serology with tumor HPV status and smoking}

Among the 137 cases with tumor tissue tested for HPV16 E6 or E7 DNA by PCR, $111(81.0 \%)$ were determined to be tumor HPV positive, and 26 (19.0\%) were tumor HPV negative. The association between serology and tumor HPV status among the cases are presented in Table 3. Of the tumor HPV positive cases, 94/111 (84.7\%) were serologically positive for at least one HPV early antigen. However, 16/26 (61.5\%) of tumor HPV negative cases were also serologically positive for at least one HPV early antigen ( $p=0.008)$. The presence of Abs to NE2, CE2, E6, and/or E7 was associated with tumor HPV status (OR [95\% CI], 6.5 [2.1-20.1]; Table 3), and this was particularly true among those who smoked less than or equal to 10 pack years (OR [95\% CI], 17.5 [4.0-77.2]; Table 3). Being seropositive to the early proteins CE2 or E7 was associated with HPV tumor status among the cases with $\leqslant 10$ pack-years of smoking but this association was not observed for late proteins (Table 3 ). Among smokers (>10 pack-years), no consistent association between seropositivity and HPV tumor status was identified (Table 3).

\section{Discussion}

Due to the rising incidence of HPV-associated oropharyngeal cancers, there is an urgent clinical need for biomarkers for early
Table 1

Demographic, exposure, and clinical characteristics of cases and controls.

\begin{tabular}{|c|c|c|c|}
\hline & Cases $n=256$ & Controls $n=250$ & $p$ \\
\hline $\begin{array}{l}\text { Age, mean (SD) } \\
\text { Age, median }\end{array}$ & $\begin{array}{l}56.5(9.6) \\
55 \\
\mathrm{~N}(\%)\end{array}$ & $\begin{array}{l}56.5(9.6) \\
55.5 \\
N(\%)\end{array}$ & $\begin{array}{l}.963 \\
.930\end{array}$ \\
\hline $\begin{array}{l}\text { Sex } \\
\text { Male } \\
\text { Female }\end{array}$ & $\begin{array}{l}220(85.9) \\
36(14.1)\end{array}$ & $\begin{array}{l}214(85.6) \\
36(14.4)\end{array}$ & .913 \\
\hline $\begin{array}{l}\text { Race } \\
\text { White } \\
\text { Other }\end{array}$ & $\begin{array}{l}233(91.0) \\
23(9.0)\end{array}$ & $\begin{array}{l}230(92.0) \\
20(8.0)\end{array}$ & .691 \\
\hline $\begin{array}{l}\text { Alcohol } \\
\text { Never } \\
\text { Former } \\
\text { Current }\end{array}$ & $\begin{array}{l}71(27.7) \\
66(25.8) \\
119(46.5)\end{array}$ & $\begin{array}{l}111(44.4) \\
47(18.8) \\
92(36.8)\end{array}$ & $<.001$ \\
\hline $\begin{array}{l}\text { Smoking } \\
\text { Never } \\
\text { Former } \\
\text { Current }\end{array}$ & $\begin{array}{l}116(45.3) \\
93(36.3) \\
47(18.4)\end{array}$ & $\begin{array}{l}131(52.4) \\
97(38.8) \\
22(8.8)\end{array}$ & .007 \\
\hline $\begin{array}{l}\text { Smoking }^{\text {a }} \\
\leqslant 10 \text { pack years } \\
>10 \text { pack years }\end{array}$ & $\begin{array}{l}149(59.6) \\
101(40.4)\end{array}$ & & \\
\hline $\begin{array}{l}\text { HPV status } \\
\text { Negative } \\
\text { Positive } \\
\text { Subsite } \\
\text { Tonsil } \\
\text { Base of tongue } \\
\text { Other oropharynx } \\
\text { Other site (not oropharynx) }\end{array}$ & $\begin{array}{l}26(19.0) \\
111(81.0) \\
122(47.7) \\
121(47.3) \\
9(3.5) \\
4(1.6)\end{array}$ & & \\
\hline $\begin{array}{l}\text { Stage } \\
\text { I-II } \\
\text { III-IV }\end{array}$ & $\begin{array}{l}19(7.4) \\
237(92.6)\end{array}$ & & \\
\hline $\begin{array}{l}\text { T category } \\
0-1 \\
2 \\
3 \\
4\end{array}$ & $\begin{array}{l}76(29.7) \\
110(43.0) \\
41(16.0) \\
29(11.3)\end{array}$ & & \\
\hline $\begin{array}{l}N \text { category } \\
0 \\
1-2 \mathrm{a} \\
2 \mathrm{~b} \\
2 \mathrm{c}-3\end{array}$ & $\begin{array}{l}29(11.3) \\
42(16.4) \\
126(49.2) \\
59(23.1)\end{array}$ & & \\
\hline $\begin{array}{l}\text { Grade }{ }^{c} \\
\text { Well to moderate } \\
\text { Moderately poor to poor }\end{array}$ & $\begin{array}{l}76(34.5) \\
144(65.5)\end{array}$ & & \\
\hline
\end{tabular}

a Total $n=250$ cases due to missing data $(n=6)$.

b Total $n=137$ cases due to missing data $(n=119)$.

c Total $n=220$ cases due to missing data $(n=36)$.

detection, diagnosis, prognosis, and monitoring of these patients. Prior studies have demonstrated that a subset of patients $(\sim 64$ 74\%) with HPVOPC have detectable Abs to HPV16 E6 and/or E7 Abs in their sera $[26,34]$. In the present study we evaluated Abs specific for a panel of eight HPV16 antigens as potential biomarkers for the diagnosis of OPC. We demonstrate that Abs to multiple HPV16 early antigens (E1, E2, E4, E5, E6, and E7) are specifically detected in the sera of patients compared with age- gender- and race-matched controls. Using these stringent cutoffs, Abs to the capsid protein L1 are rarely observed (and L2 Abs are not observed) in HPVOPC. Our data support the hypothesis that HPV16 antibody signatures may be specific and clinically useful biomarkers of HPVOPC, and potentially for other HPV-associated malignancies.

Our data confirms and extends published studies from the Pawlita laboratory demonstrating detection of E6 and E7 Abs in patients with newly diagnosed HPVOPC [26,34]. E6 Abs have been detected over 10 years prior to clinical diagnosis [35,36], but in only $35 \%$ of patients with undefined tissue HPV status, limiting 

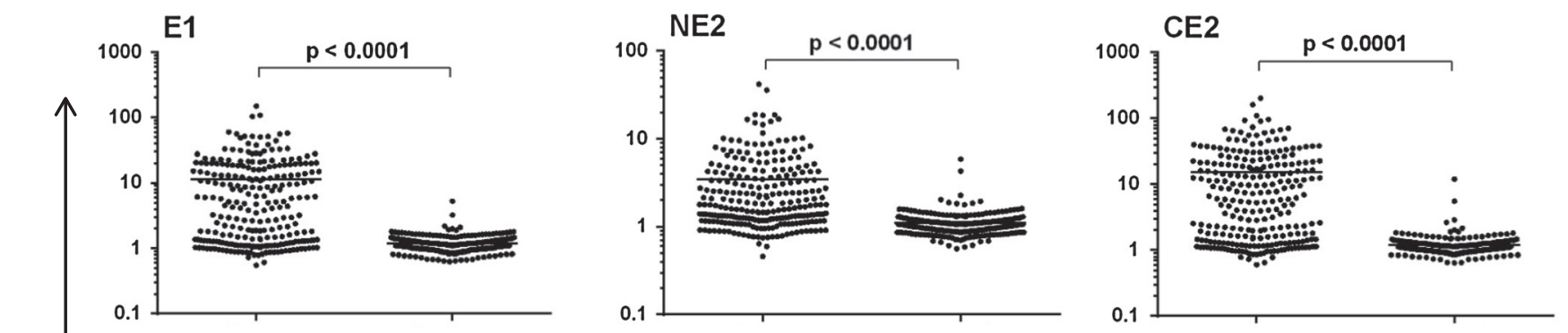

E4

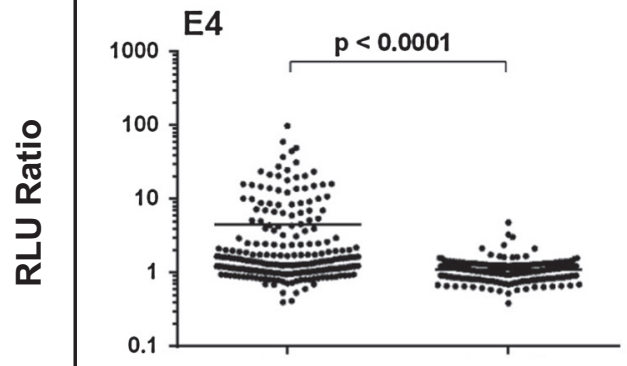

E7

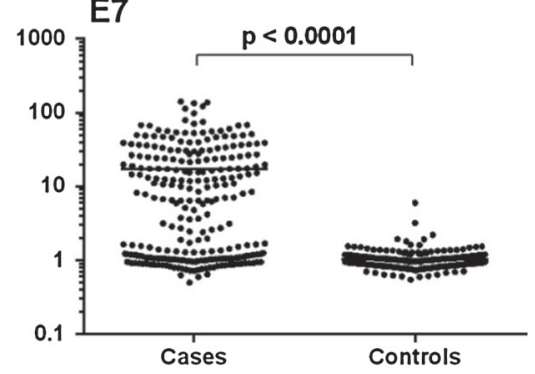

E5

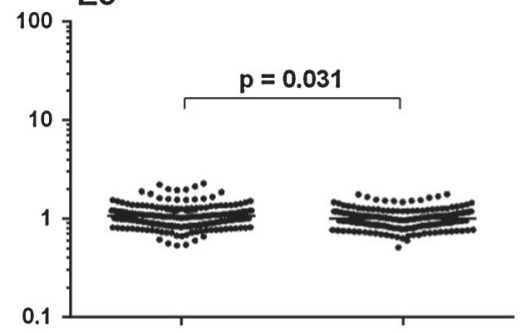

E6

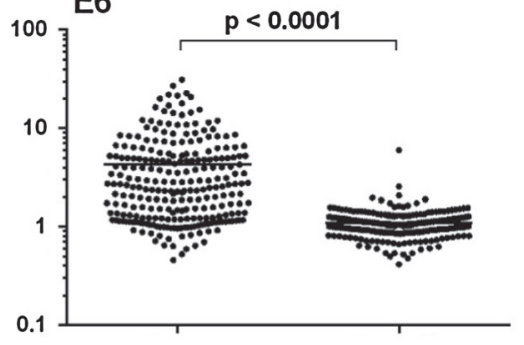

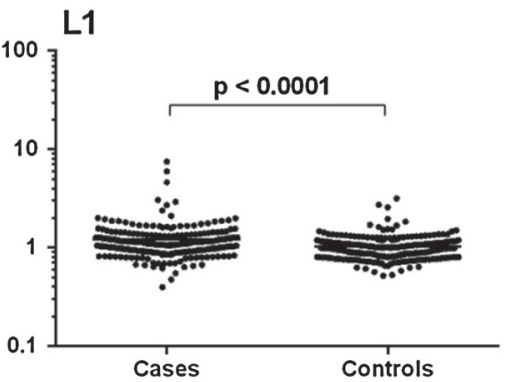

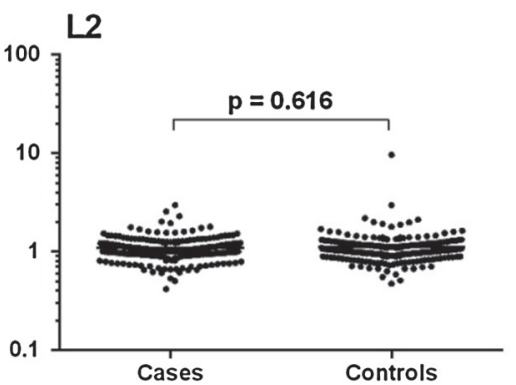

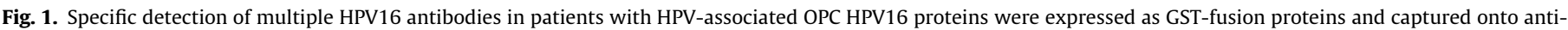
GST coated plates. The RLU ratio (RLU of HPV antigen/RLU of GST-control) of IgG detected in HPV-associated OPC sera ( $n=256)$ and controls $(n=250)$ is shown.

Table 2

Association of pre-treatment antibody status with case-control status.

\begin{tabular}{|c|c|c|c|c|c|}
\hline & $\begin{array}{l}\text { Cases } n=256 \\
\text { No. }+(\%)\end{array}$ & $\begin{array}{l}\text { Controls } n=250 \\
\text { No. }+(\%)\end{array}$ & $p^{\mathrm{b}}$ & Crude OR $(95 \% \mathrm{CI})$ & Adjusted $\mathrm{OR}^{\mathrm{C}}(95 \% \mathrm{CI})$ \\
\hline E1 & $144(56.3)$ & $2(0.8)$ & $<0.001$ & $159.4(38.8-655.1)$ & $170.6(41.3-705.0)$ \\
\hline NE2 & $104(40.6)$ & $2(0.8)$ & $<0.001$ & $84.8(20.6-348.8)$ & $85.7(20.7-354.2)$ \\
\hline CE2 & $137(53.5)$ & $2(0.8)$ & $<0.001$ & $142.8(34.7-586.5)$ & $157.5(38.0-653.2)$ \\
\hline NE2 and/or CE2 ${ }^{\mathrm{a}}$ & $144(56.3)$ & $2(0.8)$ & $<0.001$ & $159.4(38.8-655.1)$ & $177.5(42.8-736.9)$ \\
\hline E4 & $61(23.8)$ & $3(1.2)$ & $<0.001$ & $25.8(8.0-83.3)$ & $26.9(8.3-87.4)$ \\
\hline E5 & $9(3.5)$ & $2(0.8)$ & 0.063 & $4.5(1.0-21.1)$ & $4.7(1.0-22.8)$ \\
\hline E6 & $148(57.8)$ & $3(1.2)$ & $<0.001$ & $112.8(35.2-361.8)$ & $130.6(40.1-425.5)$ \\
\hline E7 & $148(57.8)$ & $3(1.2)$ & $<0.001$ & $112.8(35.2-361.8)$ & $147.4(45.0-483.1)$ \\
\hline E6 and/or E7 ${ }^{\mathrm{a}}$ & $194(75.8)$ & $6(2.4)$ & $<0.001$ & $127.2(53.9-300.4)$ & $241.4(92.6-629.4)$ \\
\hline NE2, CE2, E6, and/or E7 ${ }^{\mathrm{a}}$ & $203(79.3)$ & $7(2.8)$ & $<0.001$ & $133.0(59.2-298.9)$ & $249.1(99.3-624.9)$ \\
\hline Any $\mathrm{E}^{\mathrm{a}}$ & $210(82.0)$ & $10(4.0)$ & $<0.001$ & $109.6(53.9-222.5)$ & $243.7(101.4-586.0)$ \\
\hline $\mathrm{L} 1$ & $15(5.9)$ & $4(1.6)$ & 0.017 & $3.8(1.3-11.7)$ & $4.0(1.3-12.3)$ \\
\hline $\mathrm{L} 2$ & 0 & $1(0.4)$ & 0.494 & $\mathrm{NC}$ & $\mathrm{NC}$ \\
\hline Any $\mathrm{L}^{\mathrm{a}}$ & $15(5.9)$ & $5(6.3)$ & 0.038 & $3.0(1.1-8.5)$ & $3.1(1.1-8.8)$ \\
\hline Any $\mathrm{E}$ and/or $\mathrm{L}^{\mathrm{a}}$ & $210(82.0)$ & $12(4.8)$ & $<0.001$ & $90.5(46.7-175.5)$ & $193.8(85.0-441.5)$ \\
\hline
\end{tabular}

NC, not calculable due to zero cells.

a Any positive vs. all negative.

b Fisher's exact test.

c Adjusted for age, smoking, and alcohol status.

clinical applicability. Here, we detect E6 and/or E7 Abs in 79\% of HPVOPC patients $(n=111)$. Our results are similar to our findings of E6 and/or E7 Abs in $76 \%$ of patients $(n=119)$ with HPVOPC from the independent, multicenter HOTSPOT study [32], suggesting that there is limited regional or technical variation in serologic detection of HPVOPC. This also suggests that differences in the definition of HPV status (PCR used in this study vs p16/ISH in HOTSPOT) do not significantly impact these results. Using the full panel of early 
Table 3

Association of pre-treatment antibody status with tumor HPV and smoking status among cases.

\begin{tabular}{|c|c|c|c|c|c|c|c|c|c|c|}
\hline & $\begin{array}{l}\text { HPV- } \\
\text { (reference) } \\
n=26 \\
\text { No. }+(\%)\end{array}$ & $\begin{array}{l}\text { HPV+ } \\
n=111 \\
\text { No. }+(\%)\end{array}$ & $p$ & $\begin{array}{l}\text { Adjusted } \mathrm{OR}^{\mathrm{c}} \\
(95 \% \mathrm{CI})\end{array}$ & $\begin{array}{l}\text { HPV }+>10 \text { pack } \\
\text { years }^{\mathrm{d}} n=47 \\
\text { No. }+(\%)\end{array}$ & $p^{\mathrm{e}}$ & $\begin{array}{l}\text { Adjusted } \mathrm{OR}^{\mathrm{ef}} \\
(95 \% \mathrm{CI})\end{array}$ & $\begin{array}{l}\text { HPV }+\leqslant 10 \text { pack } \\
\text { years }^{\mathrm{d}} n=63 \\
\text { No. }+(\%)\end{array}$ & $P^{\mathrm{e}}$ & $\begin{array}{l}\text { Adjusted OR }{ }^{\text {ef }} \\
(95 \% \mathrm{CI})\end{array}$ \\
\hline E1 & $13(50.0)$ & $\begin{array}{l}66 \\
(59.5)\end{array}$ & 0.380 & $1.1(0.4-2.9)$ & $21(44.7)$ & 0.663 & $0.7(0.2-1.9)$ & $44(69.8)$ & 0.076 & $1.5(0.5-4.2)$ \\
\hline NE2 & $8(30.8)$ & $\begin{array}{l}50 \\
(45.1)\end{array}$ & 0.185 & $1.5(0.6-4.0)$ & $19(40.4)$ & 0.413 & $1.6(0.5-4.8)$ & $31(49.2)$ & 0.111 & $1.5(0.5-4.3)$ \\
\hline CE2 & $11(42.3)$ & $\begin{array}{l}68 \\
(61.3)\end{array}$ & 0.078 & $1.9(0.7-5.0)$ & $20(42.6)$ & 0.984 & $1.0(0.3-2.8)$ & $47(74.6)$ & 0.004 & $2.9(1.0-8.1)$ \\
\hline $\begin{array}{l}\text { NE2 and/or } \\
\text { CE2 }{ }^{\mathrm{a}}\end{array}$ & $11(42.3)$ & $\begin{array}{l}72 \\
(64.9)\end{array}$ & 0.034 & $2.3(0.9-6.0)$ & $22(46.8)$ & 0.711 & $1.2(0.4-3.5)$ & $49(77.8)$ & 0.001 & $3.4(1.2-9.6)$ \\
\hline $\mathrm{E} 4$ & $6(23.1)$ & $\begin{array}{l}27 \\
(24.3)\end{array}$ & 0.893 & $0.9(0.3-2.6)$ & $10(21.3)$ & 0.859 & $0.8(0.2-2.6)$ & $16(25.4)$ & 0.818 & $0.7(0.2-2.4)$ \\
\hline E5 & $2(7.7)$ & $4(3.6)$ & $0.319^{b}$ & $0.3(0-1.9)$ & $3(6.4)$ & $1.0^{\mathrm{b}}$ & $0.6(0.1-4.3)$ & $1(1.6)$ & $0.203^{\mathrm{b}}$ & $0.2(0-2.4)$ \\
\hline E6 & $10(38.5)$ & $\begin{array}{l}66 \\
(59.5)\end{array}$ & 0.052 & $2.1(0.8-5.3)$ & $24(51.1)$ & 0.301 & $1.6(0.6-4.6)$ & $42(66.7)$ & 0.014 & $2.5(0.9-7.0)$ \\
\hline E7 & $11(42.3)$ & $\begin{array}{l}68 \\
(61.3)\end{array}$ & 0.078 & $1.8(0.7-4.7)$ & $20(42.6)$ & 0.984 & $0.9(0.3-2.6)$ & $47(74.6)$ & 0.004 & $2.9(1.0-8.1)$ \\
\hline E6 and/or E7 ${ }^{\mathrm{a}}$ & $12(46.2)$ & $\begin{array}{l}88 \\
(79.3)\end{array}$ & 0.001 & $4.4(1.6-12.4)$ & $30(63.8)$ & 0.143 & $2.0(0.7-5.7)$ & $57(90.5)$ & $<0.001$ & $8.4(2.5-27.8)$ \\
\hline $\begin{array}{l}\mathrm{NE} 2, \mathrm{CE} 2, \mathrm{E} 6 \text {, } \\
\text { and/or E7 }\end{array}$ & $13(50.0)$ & $\begin{array}{l}94 \\
(84.7)\end{array}$ & $<0.001$ & $6.5(2.1-20.1)$ & $33(70.2)$ & 0.087 & $2.5(0.8-7.5)$ & $60(95.2)$ & $<0.001$ & $\begin{array}{l}17.5(4.0- \\
77.2)\end{array}$ \\
\hline Any $\mathrm{E}^{\mathrm{a}}$ & $16(61.5)$ & $\begin{array}{l}94 \\
(84.7)\end{array}$ & 0.008 & $\begin{array}{l}3.4(1.0- \\
11.4))\end{array}$ & $33(70.2)$ & 0.450 & $1.4(0.4-4.4)$ & $60(95.2)$ & $<0.001$ & $8.0(1.8-35.7)$ \\
\hline L1 & $3(11.5)$ & $6(5.4)$ & $0.371^{\mathrm{b}}$ & $0.4(0.1-1.8)$ & $3(6.4)$ & $0.659^{\mathrm{b}}$ & $0.5(0.1-2.7)$ & $3(4.8)$ & $0.352^{\mathrm{b}}$ & $0.3(0.1-2.0)$ \\
\hline L2 & 0 & 0 & NC & $\mathrm{NC}$ & 0 & NC & $\mathrm{NC}$ & 0 & $\mathrm{NC}$ & $\mathrm{NC}$ \\
\hline Any $L^{\mathrm{a}}$ & $3(11.5)$ & $6(5.4)$ & $0.371^{\mathrm{b}}$ & $0.4(0.1-1.8)$ & $3(6.4)$ & $0.659^{\mathrm{b}}$ & $0.5(0.1-2.7)$ & $3(4.8)$ & $0.352^{\mathrm{b}}$ & $0.3(0.1-2.0)$ \\
\hline Any $\mathrm{E}$ and/or $\mathrm{L}^{\mathrm{a}}$ & $16(61.5)$ & $\begin{array}{l}94 \\
(84.7)\end{array}$ & 0.008 & $3.4(1.0-11.5)$ & $33(70.2)$ & 0.450 & $1.4(0.4-4.4)$ & $60(95.2)$ & $<0.001$ & $8.0(1.8-35.7)$ \\
\hline
\end{tabular}

NC, not calculable due to zero cells.

a Any positive vs. all negative.

b Fisher's exact test.

c Adjusted for age, smoking ( $\leqslant 10$ pack years vs. $>10$ pack years), N category (N0-N2a vs. N2b-N3), and subsite (tonsil/base of tongue vs. other).

d One HPV+ case is missing pack years.

e Referent group is HPV- cases.

${ }^{\mathrm{f}}$ Adjusted for age, N category (N0-N2a vs. N2b-N3), and subsite (tonsil/base of tongue vs. other).

antigens, the proportion of patients seropositive was increased to $85 \%$, strongly supporting the use of a multiparametric signature for HPVOPC detection.

The OPC cases presented here are representative of the head and neck clinic at MD Anderson Cancer Center, as over 90\% of eligible patients consented to the study. In subset analysis, there were no correlations between age, gender, and race with seropositivity. Patients who were heavy smokers ( $>10$ pack-years) had both lower frequencies of seropositivity and no association of serology with tumor HPV16 status. Because smoking has a higher association of tumors with p53 mutation, this may represent a subpopulation where serologic biomarkers are less reliable.

One limitation of this study is the rapid evolution of methods and standards for the detection of HPV in tumor tissue in the 10 years during which these patients were enrolled [37]. There is no current standard of care for tissue biomarkers of HPV, although p16 expression detected by immunohistochemistry (IHC) is commonly used as a surrogate marker, with or without ISH for HR HPV nucleic acid [38]. Assignment of HPV status in this study was determined by PCR for HPV16 E6 and E7 [33]. Only a small subset of these cases had tissue available for p16 IHC $(n=22)$. Therefore, we did not have the ability to confirm the tissue HPV status with p16 testing.

Within the subset of cases with tissue HPV16 status identified by PCR $(n=137)$, Abs to HPV16 early antigens (E1, E2, E4, E5, E6, E7) were detected in $85 \%$ of cases who also had tumors that tested HPV16 positive by PCR, but $62 \%$ of cases that were negative by tissue HPV PCR were still positive by serology. These serologic responses were similar in strength and in antigenic specificity as the responses in tissue HPV PCR positive cases (data not shown).
Since $10-15 \%$ of HPVOPC are associated with HPV subtypes other than HPV16, we cannot exclude the possibility that the serologic assay is cross-reacting with other subtypes of HPV in the seropositive, PCR negative population. A second possibility is that the HPV16 PCR assay used in this study has limited sensitivity (false negatives), which cannot be confirmed by p16 testing in this study. We cannot exclude that we are detecting false-positive serologic responses in the HPV-negative OPC cases, but we observe no significant differences in sero-reactivity between these healthy controls from MD Anderson $(n=250)$ and Oregon Health Sciences University ( $n=78$, data not shown).

A notable finding from our data is the heterogeneity of the serologic response to HPV16 in these patients, which is of unknown biologic or clinical significance. The majority (79\%) of patient sera have Abs to E6 and/or E7, but Abs to multiple other early genes, including E1, E2, and E4 are also specifically detected. This is unique to HPVOPC, as these Abs are rarely detected in sera from patients with invasive cervical cancer (not shown). E1 Abs are strongly correlated with E2 Abs, and E4 Abs were only detected in a subset (25.7\%) of patients with E7 Abs. Five percent of patients had isolated Abs to E1/E2 antigens, without E6/E7 Abs.

A key observation from our study is the high frequency of E1 and E2 Abs in HPVOPC sera, which has not been observed in cervical disease [39]. Because humoral immunity is induced by antigen expression, we predict that the variation in the serologic response to individual HPV antigens is a result of differences in antigen expression in the tumor. Since expression of E2 decreases due to viral integration and de-repression of E6/E7 [40], we predict that Abs to E2 may inversely correlate with viral integration. As a result, E1/E2 Abs may be detected earlier in HPVOPC development than 
E6/E7 Abs. In summary, panels of antibodies to HPV16 early proteins may be highly specific biomarkers for the diagnosis of HPVOPC.

\section{Conflict of interest statement}

Dr. Anderson is a consultant, hold stock options, and serves on the scientific advisory board of Provista Diagnostics. All other authors report no conflicts of interest.

\section{Acknowledgements}

This study was supported by a research grant from the Early Detection Research Network (EDRN) U01CA117374 and Arizona State University Institutional funds (KSA), NIH/NCI R03 Grant CA128110-01A1 and CA016672 (EMS) and NCI R25T Grant CA57730 (Shine Chang, PhD, Principal Investigator) (KRD).

\section{Appendix A. Supplementary material}

Supplementary data associated with this article can be found, in the online version, at http://dx.doi.org/10.1016/j.oraloncology. 2015.04.011.

\section{References}

[1] Duvvuri U, Myers JN. Cancer of the head and neck is the sixth most common cancer worldwide. Curr Probl Surg 2009;46(2):114-7.

[2] Chaturvedi AK, Engels EA, Pfeiffer RM, Hernandez BY, Xiao W, Kim E, et al. Human papillomavirus and rising oropharyngeal cancer incidence in the United States. J Clin Oncol: Off J Am Soc Clin Oncol 2011;29(32):4294-301.

[3] D'Souza G, Kreimer AR, Viscidi R, Pawlita M, Fakhry C, Koch WM, et al. Casecontrol study of human papillomavirus and oropharyngeal cancer. New Engl J Med 2007;356(19):1944-56.

[4] Marur S, D'Souza G, Westra WH, Forastiere AA. HPV-associated head and neck cancer: a virus-related cancer epidemic. Lancet Oncol 2010;11(8):781-9.

[5] Heck JE, Berthiller J, Vaccarella S, Winn DM, Smith EM, Shan'gina O, et al. Sexual behaviours and the risk of head and neck cancers: a pooled analysis in the International Head and Neck Cancer Epidemiology (INHANCE) consortium. Int J Epidemiol 2010;39(1):166-81.

[6] Smith EM, Ritchie JM, Summersgill KF, Hoffman HT, Wang DH, Haugen TH, et al. Human papillomavirus in oral exfoliated cells and risk of head and neck cancer. J Natl Cancer Inst 2004;96(6):449-55.

[7] Hansson BG, Rosenquist K, Antonsson A, Wennerberg J, Schildt EB, Bladstrom $A$, et al. Strong association between infection with human papillomavirus and oral and oropharyngeal squamous cell carcinoma: a population-based casecontrol study in southern Sweden. Acta Otolaryngol 2005;125(12):1337-44.

[8] Gillison ML, D'Souza G, Westra W, Sugar E, Xiao W, Begum S, et al. Distinct risk factor profiles for human papillomavirus type 16-positive and human papillomavirus type 16-negative head and neck cancers. J Natl Cancer Inst 2008;100(6):407-20.

[9] Pintos J, Black MJ, Sadeghi N, Ghadirian P, Zeitouni AG, Viscidi RP, et al. Human papillomavirus infection and oral cancer: a case-control study in Montreal, Canada. Oral Oncol 2008;44(3):242-50.

[10] Tachezy R, Klozar J, Rubenstein L, Smith E, Salakova M, Smahelova J, et al. Demographic and risk factors in patients with head and neck tumors. J Med Virol 2009;81(5):878-87.

[11] Kreimer AR, Johansson M, Waterboer T, Kaaks R, Chang-Claude J, Drogen D, et al. Evaluation of human papillomavirus antibodies and risk of subsequent head and neck cancer. J Clin Oncol: Off J Am Soc Clin Oncol 2013;31(21): 2708-15.

[12] Yeudall WA, Paterson IC, Patel V, Prime SS. Presence of human papillomavirus sequences in tumour-derived human oral keratinocytes expressing mutant p53. Eur J Cancer Part B: Oral Oncol 1995;31B(2):136-43.

[13] Ferris RL, Martinez I, Sirianni N, Wang J, Lopez-Albaitero A, Gollin SM, et al Human papillomavirus-16 associated squamous cell carcinoma of the head and neck (SCCHN): a natural disease model provides insights into viral carcinogenesis. Eur J Cancer 2005;41(5):807-15.

[14] Steenbergen RD, Hermsen MA, Walboomers JM, Joenje H, Arwert F, Meijer CJ, et al. Integrated human papillomavirus type 16 and loss of heterozygosity at $11 \mathrm{q} 22$ and $18 \mathrm{q} 21$ in an oral carcinoma and its derivative cell line. Cancer Res 1995;55(22):5465-71.

[15] van Houten VM, Snijders PJ, van den Brekel MW, Kummer JA, Meijer CJ, van Leeuwen B, et al. Biological evidence that human papillomaviruses are etiologically involved in a subgroup of head and neck squamous cell carcinomas. Int J Cancer 2001;93(2):232-5.
[16] Jung AC, Briolat J, Millon R, de Reynies A, Rickman D, Thomas E, et al. Biological and clinical relevance of transcriptionally active human papillomavirus (HPV) infection in oropharynx squamous cell carcinoma. Int J Cancer 2010;126(8): 1882-94.

[17] Hoffmann M, Scheunemann D, Fazel A, Gorogh T, Kahn T, Gottschlich S. Human papillomavirus and p53 polymorphism in codon 72 in head and neck squamous cell carcinoma. Oncol Rep 2009;21(3):809-14.

[18] Smeets SJ, van der Plas M, Schaaij-Visser TB, van Veen EA, van Meerloo J Braakhuis BJ, et al. Immortalization of oral keratinocytes by functional inactivation of the p53 and pRb pathways. Int J Cancer 2011;128(7):1596-605.

[19] Lace MJ, Anson JR, Klussmann JP, Wang DH, Smith EM, Haugen TH, et al. Human papillomavirus type 16 (HPV-16) genomes integrated in head and neck cancers and in HPV-16-immortalized human keratinocyte clones express chimeric virus-cell mRNAs similar to those found in cervical cancers. J Virol 2011;85(4):1645-54.

[20] Strati K, Pitot HC, Lambert PF. Identification of biomarkers that distinguish human papillomavirus (HPV)-positive versus HPV-negative head and neck cancers in a mouse model. Proc Natl Acad Sci USA 2006;103(38):14152-7.

[21] Strati K, Lambert PF. Role of Rb-dependent and Rb-independent functions of papillomavirus E7 oncogene in head and neck cancer. Cancer Res 2007;67(24):11585-93.

[22] Anderson KS, Wong J, D'Souza G, Riemer AB, Lorch J, Haddad R, et al. Serum antibodies to the HPV16 proteome as biomarkers for head and neck cancer. $\mathrm{Br}$ J Cancer 2011;104(12):1896-905.

[23] Rubenstein LM, Smith EM, Pawlita M, Haugen TH, Hamsikova E, Turek LP. Human papillomavirus serologic follow-up response and relationship to survival in head and neck cancer: a case-comparison study. Infect Agents Cancer 2011;6:9.

[24] Smith EM, Pawlita M, Rubenstein LM, Haugen TH, Hamsikova E, Turek LP. Risk factors and survival by HPV-16 E6 and E7 antibody status in human papillomavirus positive head and neck cancer. Int J Cancer 2010;127(1):111-7.

[25] Herrero R, Castellsague X, Pawlita M, Lissowska J, Kee F, Balaram P, et al. Human papillomavirus and oral cancer: the International Agency for Research on Cancer multicenter study. J Natl Cancer Inst 2003;95(23):1772-83.

[26] D’Souza G, Kreimer AR, Viscidi R, Pawlita M, Fakhry C, Koch WM, et al. Casecontrol study of human papillomavirus and oropharyngeal cancer. N Engl J Med 2007:356(19):1944-56.

[27] Smith EM, Rubenstein LM, Ritchie JM, Lee JH, Haugen TH, Hamsikova E, et al. Does pretreatment seropositivity to human papillomavirus have prognostic significance for head and neck cancers? Cancer Epidemiol Biomar Prevent 2008;17(8):2087-96.

[28] Rubenstein LM, Smith EM, Pawlita M, Haugen TH, Hamsikova E, Turek LP. Human papillomavirus serologic follow-up response and relationship to survival in head and neck cancer: a case-comparison study. Infect Agent Cancer 2011;6:9.

[29] Anderson KS, Sibani S, Wallstrom G, Qiu J, Mendoza EA, Raphael J, et al. Protein microarray signature of autoantibody biomarkers for the early detection of breast cancer. J Proteome Res 2011:10(1):85-96.

[30] Festa F, Rollins SM, Vattem K, Hathaway M, Lorenz P, Mendoza EA, et al. Robust microarray production of freshly expressed proteins in a human milieu. Proteomics Clin Appl 2013;7(5-6):372-7.

[31] Anderson KS, Wong J, Vitonis A, Crum CP, Sluss PM, Labaer J, et al. P53 autoantibodies as potential detection and prognostic biomarkers in serous ovarian cancer. Cancer Epidemiol Biomar Prevent 2010;19(3):859-68.

[32] D’Souza G, Gross ND, Pai SI, Haddad R, Anderson KS, Rajan S, et al. Oral Human Papillomavirus (HPV) infection in HPV-positive patients with oropharyngeal cancer and their partners. J Clin Oncol: Off J Am Soc Clin Oncol 2014.

[33] Smeets SJ, Hesselink AT, Speel EJ, Haesevoets A, Snijders PJ, Pawlita M, et al. A novel algorithm for reliable detection of human papillomavirus in paraffin embedded head and neck cancer specimen. Int J Cancer 2007;121(11): 2465-72.

[34] Smith EM, Ritchie JM, Pawlita M, Rubenstein LM, Haugen TH, Turek LP, et al. Human papillomavirus seropositivity and risks of head and neck cancer. Int J Cancer 2007;120(4):825-32.

[35] Mork J, Lie AK, Glattre E, Hallmans G, Jellum E, Koskela P, et al. Human papillomavirus infection as a risk factor for squamous-cell carcinoma of the head and neck. N Engl J Med 2001;344(15):1125-31.

[36] Kreimer AR, Johansson M, Waterboer T, Kaaks R, Chang-Claude J, Drogen D, et al. Evaluation of human papillomavirus antibodies and risk of subsequent head and neck cancer. J Clin Oncol: Off J Am Soc Clin Oncol 2013.

[37] Liang C, Marsit CJ, McClean MD, Nelson HH, Christensen BC, Haddad RI, et al. Biomarkers of HPV in head and neck squamous cell carcinoma. Cancer Res 2012;72(19):5004-13.

[38] Schlecht NF, Brandwein-Gensler M, Nuovo GJ, Li M, Dunne A, Kawachi N, et al. A comparison of clinically utilized human papillomavirus detection methods in head and neck cancer. Mod Pathol 2011:24(10):1295-305.

[39] Luevano M, Bernard HU, Barrera-Saldana HA, Trevino V, Garcia-Carranca A, Villa LL, et al. High-throughput profiling of the humoral immune responses gainst thirteen human papillomavirus types by proteome microarrays. Virology 2010;405(1):31-40.

[40] Xue Y, Bellanger S, Zhang W, Lim D, Low J, Lunny D, et al. HPV16 E2 is an immediate early marker of viral infection, preceding E7 expression in precursor structures of cervical carcinoma. Cancer Res 2010;70(13):5316-25. 